\title{
Philosophy of Science in Japan 1956-1965
}

This is an attempt to continue what Hiroshi Nagai started ten years ago with his article: "Some Aspects of the Philosophy of Science in Japan" in the first issue of the Annals. From now on, however, we will try to continue this work regularly, if possible, annually. The recent development of philosophy of science in Japan, we believe, is calling for such an effort.

To begin with, the Japan Association for Philosophy of Science which represents Japan in this field of international co-operation has somehow overcome the various difficulties it had in the first years of its existence and is now slowly growing both in membership and in activity, regularly publishing a Japanese journal (Kagaku Kisoron Kenkyu) twice a year and the Annals every year. In 1959, the Association joined the International Union of History and Philosophy of Science, forming a joint national committee with the History of Science Society of Japan. Besides the annual meetings with accompanying discussions and paper-readings, it organized with the support of the Asia Foundation an international symposium on "Science and Modern Civilization" in 1958, 1960 and 1961 (cf. the Annals Vol. I, No. 4, Vol. II, No. 1 \& No. 2). It also organized an interdisciplinary symposium in collaboration with the History of Science Society of Japan under the official auspices of the Japan Science Council on "Acceptance and Significance of Modern Science in Japan" in 1961, and on "Analysis and Synthesis in Science" in 1962 and 1963.

Since 1962 another interdisciplinary organization, Science and Philosophy Symposium, supported by the Asia Foundation and the Yomiuri Shinbun Newspaper has been especially active, discussing such up-to-date and fundamental problems as "Man in Scientific Age" (cf. the Annals Vol. II, No. 4), "Mind and Body" (cf. the Japanese booklet on "Man and Machine", ed. Takahiko Yamanouchi, Tokyo, 1965), "Law and Causality", etc.

In the meantime, the Japanese Association for the Study of American Philosophy, founded by Seizi Uyeda in 1953, completed in 1960 its unique joint work on analytic philosophy with the financial assistance of the Rokefeller Foundation and the Japanese Ministery of Education. The collected, partly English-written papers were published in five well-received volumes under the following headings: 1. Logical Positivism (1954), 2. Language, Meaning and Value (1956), 3. Problems of Analytic Philosophy (1957), 4. Ways to Scientific Philosophy (1958), 5. Foundations of Contemporary Philosophy (1960).

Another group of scientific-minded philosophers and philosophic-minded scientists, the Japanese Association for Logic of Science, originally affiliated with the rather less academic-minded Institute for the Science of Thought, had been doing its modest but steady job amidst the hardships of the postwar years till 1957. Then it organized with the Japan Association for Philosophy of Science and the Japanese Association for the Study of American Philosophy the Japanese Congress of Scientific Philosophy. In recent years, however, it was maintained by a small 
devoted group around Takashi Shinohara, one of the Japanese pioneers in scientific philosophy, but last year at the ninth congress it was re-organized upon a wider co-operative basis of all philosophers and scientists concerned, so that it may develop into a truly national congress for scientific philosophy in general. The congress consists of three thematical groups: 1. Mathematics, Logic and Language, 2. Knowledge, Science and Technology, 3. Behavior, Value and History, but there are also symposiums and lectures on current problems of common interest. It now has its own printed organ: Kagaku Tetsugaku Nenpo.

Monographs published during the last decade on philosophy of science or scientific philosophy in general are not many, if we disregard textbooks of logic. Research work in logic is now carried out more and more by mathematicians like G. Takeuti, S. Maehara and A. Nakamura.

On the tradional line of prewar philosophers of science like Hajime Tanabe (cf. H. Nagai's aforementioned article), we have two voluminous works by Hiroshi Nagai, "The Ontological Foundation of Mathematics" (1962) and "Studies in Contemporary Natural Philosophy" (1963), and on the modern line of analytic philosophy Shigeo Nagai's "Analytic Philosophy-Logical Foundation of Language Analysis" (1959), Saburo Ichii's "Philosophical Analysis-Essays on the Foundations of Society, History and Logic" (1963) and Nobushige Sawada's "Philosophy and Logic-Logical Analysis and Philosophical Synthesis" (1964). The English-written article by Seizo Ohe, "The Multiple Structure of our External Knowledge" in the Unesco-sponsored "Philosophical Studies of Japan" Vol. V (1964), may be of novel interest. The most interesting figures among contemporary scientific philosophers in Japan, however, are Shozo Ohmori, a solipsistic sceptic, and Natuhiko Yosida, an optimistic relativist, as they are represented in "Philosophy of Scientific Age" (1964), a collection of twenty eight papers and two symposium proceedings complied by J. Aomi, A. Ishimoto, S. Ohmori, N. Sawada and N. Yosida into three volumes with the following titles respectively: 1. Logic, Science and Philosophy, 2. Manand Society, 3. Nature and Knowledge.

On the other hand, another interdisciplinary movement is developing along with the project of an independent national Institute of Behavioral Science in the Japan Science Council. A new periodical named "Behavioral Science Research" was issued last year by Tokai University in Tokyo. Scientific, particularly statistical studies on the national character of the Japanese are also in vogue. Scientific revolution thus begins to penetrate even into the irrational core of the Japanese personality. Could it then bring about a revolution in the Japanese mind itself? An American Fulbrighter in Kyoto 1962-63, Prof. Edward W. Barankin of California, on the contrary, deeply inspired by the radical positivism of Zen philosophy, energetically urged Japanese intellectuals to look into their precious tradition anew and to search for a scientific re-orientation in this area. (See his article on "Probability and the East" and commentaries with his replies in the Annals of the Institute of Statistical Mathematics, Vol. XVI, No. 3, Tokyo, 1964.) We might also add hereto that Zyoiti Suetuna, President of the Japan Association for Philosophy of Science since 1962, has long been trying to ground man's whole intellectual activity upon the deepest tradition of Buddhist contemplation, quietly warning, he too, our younger generation that logic and language analysis can only be a means, not an end.

(S. Ohe) 